\title{
Sunshine Wine on the Nile
}

\author{
Nicole Hansen
}

\section{Introduction}

In his 1982 work Weinstudien: Untersuchungen zu Anbau, Produktion und Konsum des Weins im arabisch-islamischen Mittelalter, Peter Heine devoted a chapter to wine production methods. While he collected valuable evidence, he treated wine production across Arabic-speaking countries as undifferentiated, giving short shrift to regional variations. He also relied solely on lexical texts and poetry to reconstruct the methods of wine production. ${ }^{1}$

This approach is not surprising, for the study of the early Islamic period in Egypt has been traditionally based on non-documentary textual evidence. However, such texts alone only give us a small part of a bigger picture. Archaeology is the study of the traces left behind by human activity. While not necessarily as deliberate an act of leaving a record as writing a text, these traces are important for our understanding of history. Equally important for supplementing our knowledge is art, a non-verbal alternative to textual documentation, but similar to textual sources in that it is a product of the human hand and a human desire to record information for future consultation. Finally, ethnographic evidence, or in the case of this article, the observations of early European travelers to Egypt, is invaluable.

Five years after Heine's work appeared, an early Arabic cookbook was published, which forms the focus of this article: the Kitāb al-Ṭabikh of Abū Muhammad al-Muẓaffar ibn Nașr ibn Sayyār al-Warrāq. It was probably compiled in the second half of the tenth century CE in Baghdad. Several manuscript copies are known. ${ }^{2}$ Most of the recipes in this cookbook are not identified by the region from which they come. But two recipes for wine are identified as Egyptian. In an attempt to better understand these early Islamic period recipes, I will draw upon evidence from earlier and later time periods, and also expand the type of evidence considered. The ancient Egyptians depicted the preparation of food and beverages frequently in their tombs and temples, and archaeologi-

\footnotetext{
1 Heine, Weinstudien 31.

2 al-Warrāq, Kitāb al-Ṭabīkh.

(C) NICOLE HANSEN, 2015 | DOI:10.1163/9789004284340_016

This is an open access chapter distributed under the terms of the prevailing CC-BY-NC License at the time of publication.
} 
cal remains help fill in some of the gaps in our knowledge. Non-Arabic texts and early European travelers' accounts round out the sources. Examined together with these other sources, these two recipes are of great importance in tracing and reconstructing winemaking techniques used in Egypt from prehistory to the present day.

\section{The Role of Wine in Early Islamic Egypt}

The manufacture of wine faced a challenge at the beginning of the eleventh century CE in Egypt. Al-Hākim (Fatimid caliph r. 374-411/985-1021), a ruler known for a number of bizarre and strict rules he imposed on the people, prohibited the import and sale of raisins to Egypt in order to stamp out wine production. Raisins were burned, thrown in the Nile, or thrown in the streets and trodden upon. The vineyards of Giza were cut down and he gave orders for the same to be carried out elsewhere. Five thousand jars of honey were dumped in the Nile. ${ }^{3}$ What were the drinks made from these raisins, grapes and honey that inspired these acts?

These beverages were actually among the most popular of the time. 'Alì ibn Raḍwān, who lived during the eleventh century CE, described Egypt's vintages thus: "The favoured drink among the people is al-Shamsi (sunny) because the honey in it preserves its strength and does not allow it to change quickly. The beverage is made when the weather is hot, so that the heat brings the drink to maturity. The raisins used in it are imported from a country with better air. Concerning Egyptian wine, it is rare that honey is not added when it is pressed. Because wine is pressed from native grapes, it resembles their temperament, and therefore the people prefer al-Shamsī to it." ${ }^{4}$

During the early Islamic period and later, wine production was mainly in the hands of Christians and Jews. ${ }^{5}$ Monasteries were large-scale producers of wine during the sixth through eighth centuries CE; in particular, Bawit and Wadi Sarga were important centres for winemaking, and at least at the latter, wine was the biggest source of revenue. ${ }^{6}$ During the twelfth century, the Arabic texts indicate wine was still made widely in monasteries. ${ }^{7}$

3 Heine, Weinstudien 50; Lutz, Viticulture 5-6.

4 Ridwan, Medieval 91 (English), 7 (Arabic).

5 Heine, Weinstudien 31.

6 Bacot, La circulation 272-273, 284. For wine production in Bawit, see also P.Brux.Bawit, 93-94. For other places in Egypt, see for example Bacot, Le vin(Edfou), Konstantinidou, Aspects (Wadi Natrun) and more generally Dixneuf, Amphores.

7 Monneret de Villard, Il monastero 89. 
Monneret de Villard argued that wine production remained common in Egypt from the coming of Islam to at least the twelfth century. He found many Coptic documents mentioning wine in the Vienna papyrus collection, and a number of Arabic ones as well, dating from $724-887 \mathrm{CE}$, mostly from the Fayyūm. ${ }^{8}$ The association of the Fayyūm with wine was long lasting. In the seventeenth century CE, a European visitor to the Fayyūm described the making of wine there. ${ }^{9}$ It remained the sole province producing wine when the French invaded Egypt, and they quickly recognised that the methods used were the same as those depicted on ancient tomb walls. ${ }^{10}$

\section{Honey Wine}

The first recipe for Egyptian wine in the cookbook is for a so-called "honey wine" or a mead. I will give the Arabic version,11 with my own translation, interspersed with relevant commentary:

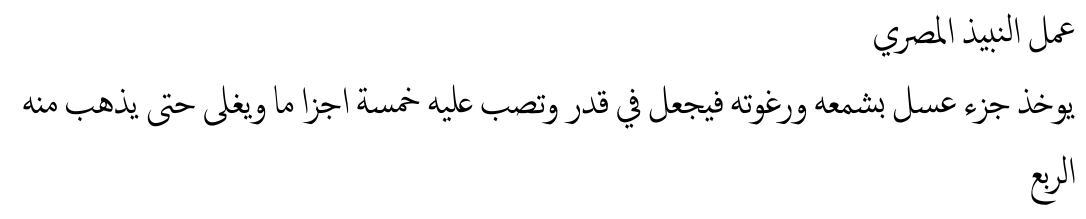

Making Egyptian Wine

Take one part honey with its wax and its froth and put it in a pot and pour five parts water on it and boil it until it is reduced by a quarter.

Arabic texts tell us that grapes were pressed, and presumably picked, in July, August and September. ${ }^{12}$ Several Greek texts indicate grapes were picked between the end of July and the middle of August. ${ }^{13}$ While we do not have such detailed records from ancient times, wine was closely tied in ancient Egypt with the star Sirius, which rose in mid-summer. ${ }^{14}$ Arabic sources indicate that honey

$8 \quad$ Ibid., 88.

$9 \quad$ Vansleb, Nouvelle $255^{-256 .}$

10 Gerard, Details 129-130.

11 As published in al-Warrāq, Kitāb al-Ṭabīkh 303. Cf. Nasrallah, Annals 462.

12 Heine, Weinstudien 32; Pellat, Cinq 247.

13 Kruit, The meaning 273; Rathbone, Economic 250.

14 Meeks, Oléiculture 20. 
was collected mainly in June and the work finished in July, just as the grape harvest and pressing began. ${ }^{15}$

Thus it is not surprising to find a close connection between honey and grape-based beverages. We see this close association in the paper by Alain Delattre in this volume. The pre-Islamic predecessor of this so-called "Egyptian wine" made from honey was something known in Greco-Roman times and

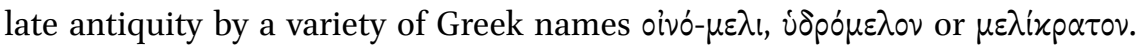
This mixture of honey and water was used frequently in Greek medicine and appears in even earlier Greek medical papyri. It also could be used in dyeing and alchemy. ${ }^{16}$ This beverage may have an even more ancient history. It has been suggested that two ancient scenes, one from a temple and the other from a tomb, represent the making of such a fermented honey drink. ${ }^{17}$

The next line of our text reads:

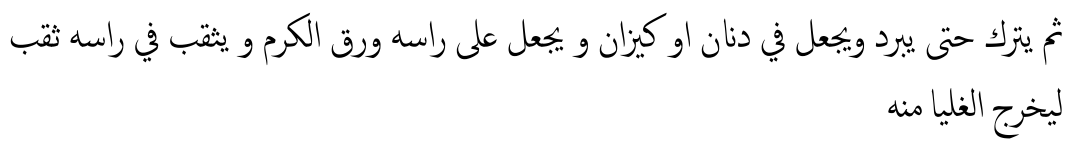

Then leave it until it cools and put it in an earthenware wine jug or large vessel with handles and put grape leaves on top of it and pierce its neck with a hole to allow the fermentation gases to escape from it.

This description is very close to a find dating probably to the seventh century CE from the Monastery of Epiphanius in Luxor of amphorae with wads of vine leaves stuffed into the necks and then covered over with a $10 \mathrm{~cm}$ high stopper of mud and chopped straw. ${ }^{18}$ Rush bungs were used as stoppers in the wine jars found in King Tutankhamun's (pharaoh r. ca. 1332-1323 BCE) tomb and at the palace of Malqata belonging to Amenhotep III (pharaoh r. ca. 1386-1349 BCE). Other ancient stoppers found include those made from a circular reed mat, a bung of chopped chaff mixed with adhesive, a bung of chaff with mud, reed wadded up in a ball, or even a pottery stopper (either a disc or a shard of pottery). ${ }^{19}$

15 Pellat, Cinq 231. However, in modern times honey is not collected during the summer (Kuény, Scènes 9o).

16 P. Alex inv. 291 (Andorlini, Greek 166); Chouliara-Raïos, L'Abeille 150-151.

17 Kuény, Scènes 92.

18 Winlock and Crum, The monastery 79.

19 Hope, Jar sealings 14; Lesko, King 20. 
The effect of summer heat under which this fermentation took place is represented in ancient tomb scenes showing wine jars overflowing. ${ }^{20}$ In one relief, the overflowing jars were being fanned by a man, perhaps in a futile attempt to keep them cool. ${ }^{21}$

Piercing a hole in the neck relieved the pressure of the turbulent fermentation going on inside. Holes for the fermentation to escape in the jars from the Monastery of Epiphanius were either made in the mud stopper or drilled directly into the neck of the jar with a metal awl or something similar after baking. ${ }^{22}$ Similar artefacts were found at a monastery in Meinarti in Nubia. There, holes had been drilled in the necks of the pitched jars, which were then sealed with mud. This work took place in a chamber adjacent to the monastery's refectory. ${ }^{23}$ During his excavations on the shores of Lake Maryut, Empereur found amphorae with holes in their necks. ${ }^{24}$ In fact, one ancient tomb scene depicts the collection of taxes and among the remittances are jars labelled as honey. The mud covers on these jars are depicted with what may be holes identical to those depicted in paintings of wine jars, although these could simply be seals. $^{25}$

These methods date back at least to the earliest period of Egyptian history. Wine jars found at the Early Dynastic sites of Saqqara and Abydos had such holes. ${ }^{26}$ New Kingdom tomb scenes depict wine jars with square-topped seals with such holes clearly illustrated. ${ }^{27}$

Lerstrup and Mayerson have argued that such holes may not have been used to allow the secondary fermentation to escape, for they do not occur in all wine jars, and the latter has suggested they were instead used to draw the wine out of the jars. ${ }^{28}$ These arguments are not convincing, for at least two reasons. First, these holes are not always very easy to see and therefore may have been more common than previously noted..$^{29}$ Secondly, many of the surviving wine jars did not have their original stoppers, as it seems that some wine was rebottled

\footnotetext{
20 Davies, The tombs pl. xxx.

21 Davies and Gardiner, The tomb pl. xxvI.

22 Winlock and Crum, The monastery 79.

23 Adams, The vintage 283.

24 Empereur, La production 42.

25 Meeks, Oléiculture 23 n. 135.

26 James, The earliest 198.

27 Davies, The tombs pl. xxx; Säve-Söderbergh, Four pl. xv.

28 Lerstrup, The making 73; Mayerson, Jar stoppers 219-220.

29 James, The earliest 198.
} 
after it reached its final destination, thus there would be no secondary fermentation lock. ${ }^{30}$

One is next instructed thus:

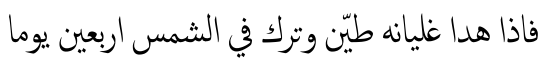

When its fermentation subsides, coat it with clay and leave it in the sun for forty days.

This describes a process that is well attested during Greco-Roman times in Egypt. In those days, wine was left to age in sunning areas known as $\dot{\eta} \lambda ı \alpha \sigma \tau \dot{\eta}-$ pıov. The first mention we have of a $\dot{\eta} \lambda ı \alpha \tau \dot{p}$ pıov was not actually from a Greek papyrus, but from a demotic one that dates to between 107-30 BCE. ${ }^{31}$ We know from texts that the $\dot{\eta} \lambda \iota \alpha \sigma \tau \dot{\eta}$ pıov was well-guarded and had locks and keys. ${ }^{32}$ Two

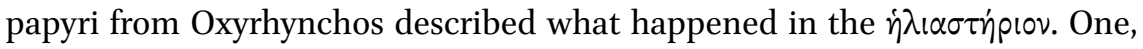
dating to $257 \mathrm{CE}$ said, "And when these [jars] have been filled with wine, we shall place them in the sunning area, seal them, move them, and guard them for as long as they stay there ..." ${ }^{33}$ However, the presence of a guard may have not been simply for the purpose of protecting against theft, but also to ensure that the wine was fermenting properly. A papyrus from Oxyrynchus detailing an inspection of wine amphorae before they were sealed deemed a number of them undrinkable because they had turned to vinegar. ${ }^{34}$ An intriguing tomb scene from the New Kingdom seems to indicate that the history of the $\dot{\eta} \lambda_{l-}$ $\alpha \sigma \tau$ '́p enclosure filled with wine jars (the guard however seems to have tasted a little too much wine and has fallen asleep on the job). The walls of the enclosure are shown with undulating tops. Säve-Söderberg suggested that these walls might represent the walls of an enclosure, rather than a wine cellar. However,

$30 \quad$ McGovern, Wine 91-95. Additional evidence that wine was rebottled after reaching its destination is a limestone stamp found in Tuthmosis Iv's (pharaoh r. 14th c. BCE) temple at Thebes used to stamp wine as coming from an area in the Delta (Petrie, Six 3 ). Moreover, among the pierced jar sealings found at Amenhotep III's temple at Malqata, two were for jars containing fat, suggesting that jars originally used to ship wine to Thebes were reused to hold other substances (Hope, Jar sealings 7).

31 P. Dem. Gieben 2 (Vandorpe and Clarysse, A Greek 131). The word was written in demotic as h'ly'stryn.

32 Vandorpe and Clarysse, A Greek 129.

33 Mayerson, $\alpha \mu \pi \varepsilon \lambda$ ouprov 188. See also Rathbone, Economic 253.

34 P. Oxy. 1673 (Brun, Le vin 71). 
he thought this was simply a temporary storage location, rather than an integral part of the winemaking process. ${ }^{35}$ However, I would argue that it might actually represent a $\dot{\eta} \lambda \iota \alpha \tau \tau^{\prime} \rho 10 v .{ }^{36}$ Another tomb scene depicts a garden surrounded by an undulating wall. ${ }^{37}$ Such undulating brick walls have been found by archaeologists and were used as enclosure walls of cult temple complexes. ${ }^{38}$ Therefore, it seems such walls were used for open areas such as the $\dot{\eta} \lambda ı \alpha \sigma \tau \dot{\eta} \rho 10 v$, not for roofed enclosures.

The Geniza documents contain a recipe for "good wine" that involved mixing honey with spices, plastering the jar over, and leaving it in the sun for 7 days. Shamsì is specifically mentioned elsewhere in the Geniza documents. ${ }^{39}$ Vansleb, a seventeenth-century visitor to Egypt observed that wine was left open in the sun in those days. ${ }^{40}$

Finally we read:

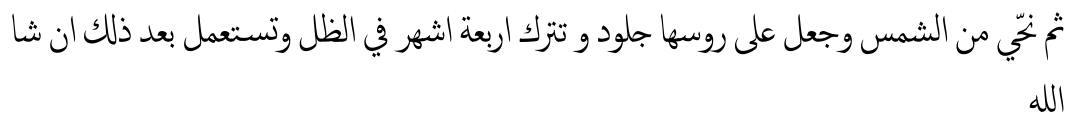

Then remove it from the sun and put skins on its necks and leave it for four months in the shade and then use it after that, God willing.

The Greek texts indicate there were two stages of fermentation of wine: one of two weeks, another of several months. ${ }^{41}$ From one Greek papyrus, it can be deduced that the period of fermentation of grape wine was similar in the Greco-Roman period. In this text, the author wrote that he had not sealed some wine jars because the merchants wished to wait until December 31 to ascertain whether the wine had a good odour before purchasing it. ${ }^{42}$ In Greco-Roman times, wine was drawn from the vats between December and March. ${ }^{43}$

35 Säve-Söderbergh, Four 18.

36 Säve-Söderbergh, Four pl. xv.

37 Wilkinson, The manners 143.

38 Spencer, Brick 114-116.

39 ENA 2808, f. 22 (Goitein, A Mediterranean society).

$40 \quad$ Vansleb, Nouvelle $255^{-256 .}$

41 Kruit, The meaning 273.

42 P. Oxy. 1673 (Brun, Le vin 71).

$43 \quad$ Kruit, The meaning 273. 


\section{Raisin Wine}

The second recipe is for a raisin wine:

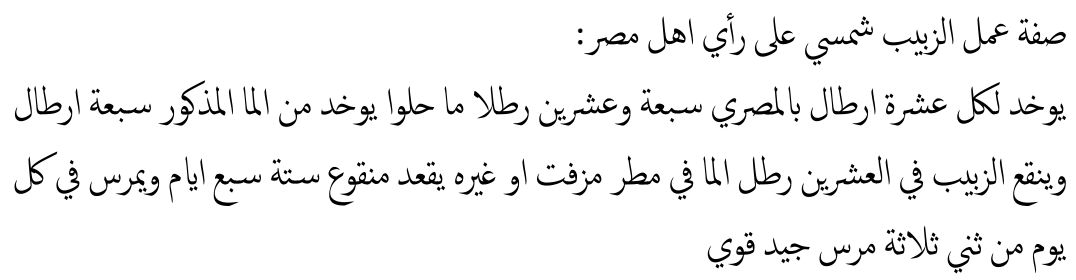

Recipe for making 'Sunshine' Raisin (Drink) According to the Custom of the People of Egypt

For every 10 Egyptian rațls [of raisins] take 27 rațls of sweet water. Take from this water 7 rațls and soak the raisins in 20 rațls of water in a pitched or unpitched Byzantine amphora and let it sit soaking for 6 or 7 days, squeezing it strongly two or three times every day.

The Eucharistic wine of the Coptic Church is normally made from raisins. The raisins are cleaned with water and then placed in an earthenware pot filled with water to a depth of six centimetres above the raisins. They are soaked for three to five days, after which they are removed and squeezed. ${ }^{44}$ Wine made from raisins was also esteemed in Napoleon's time as a source of vinegar. In those days, the raisins used were often imported from Cyprus or Greece. ${ }^{45}$

The amphorae at the monastery of Epiphanius also were smeared with a resinous pitch for the clay of the jar would have otherwise been too porous to keep the wine from evaporating. ${ }^{46}$

Two hundred years ago, the wine was first put in cylindrical earthenware jars and allowed to ferment for eight to fifteen days. ${ }^{47}$ In Vansleb's day, this initial fermentation period lasted seven days, like in our text. ${ }^{48}$

\footnotetext{
44 Khs-Burmester, The Egyptian 113.

45 Girard, Details 235.

46 Winlock and Crum, The monastery 79 .

47 Gerard, Details 130.

48 Vansleb, Nouvelle $255^{-256 .}$
} 


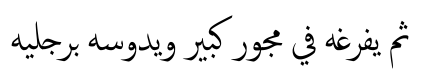

Then you pour it into a large trough and crush it with the feet.

Ancient Egyptians treaded grapes with the feet to release their juices. This is frequently depicted in ancient tomb scenes. ${ }^{49}$ It is also mentioned in Greek language texts from Egypt. ${ }^{50}$ The French savants noted that the grapes were first crushed for about an hour in an earthenware jar. ${ }^{51} \mathrm{~A}$ number of large crushing installations have been unearthed, the earliest dating to the New Kingdom at the site of Tell el-Daba, but also a fair number from the Byzantine Period. In fact, one such installation was found at the site of Marea and another very similar one was excavated at Abu Mina both possibly dating to the fifth or sixth century CE. ${ }^{52}$

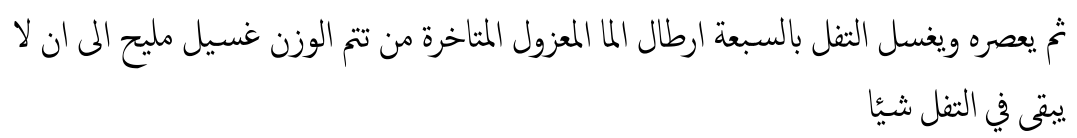

and then you press it and wash the sediment with the seven raț of water left over until no sediment is left.

Napoleon's scholars witnessed the grapes being put in a wool sack and twisted to squeeze out their juice. ${ }^{53}$ Grapes were pressed in a similar manner in ancient Egypt, but in a linen sack. ${ }^{54}$

$$
\text { وريصفيه ويضاف اليم يفلش شثمر غريض وبلاب فلوش مرتين اخضر وبثمن دراهم ورق رند واوقية زر }
$$

And strain it and add to it 1 fals of fresh fennel seeds, 3 fals fresh wormwood and rosebay (murratayn akhdar), 8 dirhams of bay leaves and an

\footnotetext{
49 For an overview of treading grapes in ancient Egypt, see Murray, Boulton, and Heron, Viticulture $586-588$.

50 Rathbone, Economic 253-254.

51 Gerard, Details 130.

52 al-Fakharani, Recent 183-184.

53 Gerard, Details 130.

54 Montet, La fabrication 120-124.
} 
uqiyya of rose petals and sweeten it with 3 rațls of excellent-quality fermented dough ( fatțara 'a $\mathrm{a} l) .{ }^{55}$

Wine made from raisins, known as "straw wine" in Europe, is extremely sweet and needs no extra sweeteners. ${ }^{56}$ In fact, according to Heine, additives like pepper, saffron, rosewater and musk were often used to compensate for the overly sweet taste of some wines. ${ }^{57}$ However, in this case some sort of sweetener was also added. The "good wine" in the Geniza texts that I mentioned earlier was suggested by Goitein to simply be a syrupy additive to flavour grape wine. ${ }^{58}$ In our recipe, it seems that something similar was happening.

$$
\text { ويوعى في الجرار ويكط في الشمس اسبوعين وان اضاف اليه دردى الخميرة كان اصلح }
$$

and put it in a bottle and put it in the sun for two weeks and if you add the dregs of yeast it will be better.

The bottle used here, the jarra, had a tall neck and two handles and was the kind of vessel in which wine was normally sold. ${ }^{59}$ According to Napoleon's savants, the fermented wine was finally poured off into jars that had been used to import oil into Egypt, buried up to their neck, and then sealed. ${ }^{60}$ The juice of the Eucharistic wine is poured into vessels in which they are allowed to ferment for at least forty days, after which it may be used for the Eucharist. ${ }^{61}$ Adding yeast would have helped to speed up the fermentation process and may have been necessary if the wine were made in winter from raisins dried during the previous summer's harvest.

\section{Conclusion}

While wine remained a drink of the elite throughout pharaonic times, its production methods are well-attested in visual and archaeological sources. In

55 As Nasrallah (Annals, 262 n.13) points out there are a number of Egyptian dialectal forms in this recipe such as reading 'sh' for 's.'

$5^{6}$ Heine, Weinstudien $34-35$.

57 Ibid., 82.

$5^{8}$ Goitein, A Mediterranean society 260.

59 Heine, Weinstudien 85.

6o Gerard, Details 130.

61 Khs-Burmester, The Egyptian 82. According to Butler (The Ancient 281), this wine is not fermented, but from his description of its manufacture, this seems unlikely. 
Greco-Roman times, wine became a drink of the masses and its production is mentioned frequently in both Greek and Demotic texts. Although the coming of Islam gradually reduced the importance of wine as a beverage, it continued to be manufactured in the monasteries and in the Fayyum until recent centuries as attested by textual, archaeological and ethnographic sources. By tracing this process through the full range of sources available, it is apparent that winemaking in Egypt is an unbroken tradition of at least 5000 years. The climate and agricultural seasons played a pivotal role in shaping and maintaining the particular process and nature of Egyptian wine that distinguishes it from the wine in other parts of the Middle East, to the extent that Ibn al-Warrāq specifically indicated that two recipes in his compilation were Egyptian ones.

\section{Bibliography}

\section{Primary Source}

al-Warrāq, Ibn Sayyār (1oth century), Kitāb al-Ṭabīkh (Studia orientalia 6o), ed. K. Öhrnberg and S. Mroueh, Helsinki 1987.

\section{Secondary Sources}

Adams, W.Y., The vintage of Nubia, in Kush. Journal of the Sudan Antiquities Service 14 (1966), 262-283.

Andorlini, I. (ed.), Greek medical papyri I, Florence 2001.

Bacot, S., La circulation du vin dans les monastères d'Égypte à l' Époque Copte, in N. Grimal and B. Menu (eds.), Le commerce en Égypte ancienne (Bibliothèque d'Étude 121), Cairo 1998, 269-288.

—. Le vin à Edfou, in Cahiers de la céramique égyptienne 8 (2007), 713-720.

Brun, J.-P., Le vin et l'Huile dans le Méditerranée antique: Viticulture, oléiculture et procèdes de transformation, Paris 2003.

Butler, A.J., The ancient Coptic churches of Egypt, vol. 2, Oxford 1884.

Chouliara-Raïos, H., L'abeille et le miel en Égypte d'après les papyrus Grecs, Jannina, Greece 1989 .

Davies, N. de G., The tombs of two officials of Tuthmosis the Fourth (nos. 75 and 9o) (Theban tomb series 3), London 1923.

and A.H. Gardiner, The tomb of Amenemhet (no. 82) (Theban tomb series 1), London 1915.

Dixneuf, D., Amphores égyptiennes. Production, typologie, contenu et diffusion (IIIe siècle avant J.-C.-IXe siècle après J.-C.), Alexandria 2011.

Empereur, J.-Y., La production viticole dans l'Égypte Ptolémaïque et Romaine, in M.C. Amouretti and J.-P. Brun (eds.), La production du vin et de l'Huile en Méditerranée (Supplément au bulletin de correspondance hellénique 26), Athens 1993, 39-47. 
al-Fakharani, F., Recent excavations at Marea in Egypt, in Das Römisch-Byzantinische Ägypten: Akten des internationalen Symposions, 26-3o September 1978 in Trier (Aegyptiaca Treverensia 2), Mainz am Rhein 1983, 175-186.

Gerard, P.S., Details particuliers sur les antiquités et autres faits remarquables, in A. Galland (ed.), Tableau de l'Égypte, pendant le séjour de l'Armée Française, Paris 1803, 124-130.

_. Mémoire sur l' agriculture, l' industrie et le commerce de l'Égypte, in P.S. Gerard (ed.), Description de l'Egypte, vol. 17, Paris 1809, 491-711.

Goitein, S.D., A Mediterranean society: The Jewish communities of the Arab world as portrayed in the documents of the Cairo Geniza, vol. 4, Berkeley and Los Angeles 1983.

Heine, P., Weinstudien: Untersuchungen zu Anbau, Produktion und Konsum des Weins im arabisch-islamischen Mittelalter, Wiesbaden 1982.

Hoch, J.E., Semitic words in Egyptian texts of the New Kingdom and Third Intermediate period, Princeton 1994.

Hope, C., Jar sealings and amphorae of the eighteenth Dynasty: A technological study, in Egyptology Today 2/5 (1977), 1-88.

James, T.G., The earliest history of wine and its importance in ancient Egypt, in P.E. McGovern, S.J. Fleming and S.H. Katz (eds.), The origins and ancient history of wine (food and nutrition in history and anthropology 11), Amsterdam 1996, 197-213.

Khs-Burmester, O.H., The Egyptian or Coptic church: A detailed description of her liturgical services and the rites and ceremonies observed in the administration of her sacraments, Cairo 1967.

Konstantinidou, A., Aspects of everyday life in a monastic settlement: Amphorae and cooking wares (4th-7th) from the old monastery of Baramus in the Wadi Natrun (Egypt): A first glance, in: LRCW3 late Roman coarse wares, cooking wares and amphorae in the Mediterranean, vol. 2, Oxford 2010, 951-961.

Kruit, N., The meaning of various words related to wine, in Zeitschrift für Papyrologie und Epigraphik 90 (1992), 265-276.

Kuény, G., Scènes apicoles dans l' ancienne Égypte, in Journal of Near Eastern studies 9 (1950), 84-93.

Lerstrup, A., The making of wine in Egypt, in Göttinger Miszellen 129 (1992), 61-82.

Lesko, L.H., King Tut's wine cellar, Berkeley 1977.

Lutz, H.F., Viticulture and brewing in the ancient Orient, Leipzig 1922.

Mayerson, P., Jar stoppers and the sealing of winejars, in Zeitschrift für Papyrologie und Epigraphik 136 (2001), 217-220.

$\alpha \mu \pi \varepsilon \lambda$ ouprov: More than a 'vine dresser,' in Bulletin of the American society of papyrologists 40 (2003), 187-190.

McGovern, P.E., Wine of Egypt's golden age: Archaeochemical perspective, in Journal of Egyptian archaeology 83 (1997), 69-108.

Meeks, D. Oléiculture et viticulture dans l'Égypte pharaonique, in M.-C. Amouretti and 
J.-P. Brun (eds.), La production du vin et de l'Huile en Méditerranée (Supplément au bulletin de correspondance hellénique 26), Athens 1993, 3-38.

Monneret de Villard, U., Il monastero di S. Simeone presso Aswân, vol. 1, Milan 1927.

Montet, P., La fabrication du vin dans les tombeaux antérieurs au Nouvel Empire, in Recueil de Travaux relatifs à la philologie et à l'archéologie égyptiennes et Assyriennes 35 (1913), 117-124.

Murray, M.A., N. Boulton and C. Heron, Viticulture and wine production, in P. Nicholson and I. Shaw (eds.), Ancient Egyptian materials and technology, Cambridge 2000, 577-6o8.

Nasrallah, N., Annals of the Caliphs' kitchens: Ibn Sayyār al-Warrāq's tenth century Baghdadi cookbook, Leiden 2010.

Pellat, C., Cinq calendriers Égyptiens, Cairo 1986.

Petrie, W.M.F., Six temples at Thebes, London 1897.

Rathbone, D., Economic rationalism and rural society in third-century AD Egypt: The Heroninos archive and the Appianus estate, Cambridge 1991.

Ridwan, A., Medieval Islamic medicine, Berkeley and Los Angeles 1984.

Säve-Söderbergh, T., Four Eighteenth Dynasty tombs (Private tombs at Thebes 1), Oxford 1967.

Spencer, A.J., Brick architecture in ancient Egypt, Warminster 1979.

Vandorpe, K. and W. Clarysse, A Greek winery for sale in a Fayum demotic papyrus, in A.M.F.W. Verhoogt and S.P. Vleeming (eds.), The two faces of Graeco-Roman Egypt: Greek and demotic and Greek-demotic texts and studies presented to P.W. Pestman (Papyrologica Lugduno-Batava 30), Leiden 1998, 127-139.

Vansleb, P., Nouvelle Relation en forme de iournal d' un voyage fait en Égypte en 1672-1673, Paris 1677.

Wilkinson, G., The manners and customs of the ancient Egyptians, 3rd ed., London 1847. Winlock, H.E. and W.E. Crum, The Monastery of Epiphanius at Thebes. Part I: The Archaeological material, the literary material. Publicaitons of the Metropolitan Museum of Art, Egyptian Expedition 3, New York 1926. 